\title{
THE TREAT OF USING OF EXPLOSIVES DURING MASS CULTURAL AND SOCIAL EVENTS
}

\author{
Štefan JANGL ${ }^{1}$, Lucia FIGULI ${ }^{2}$, Zuzana LIGASOVÁ ${ }^{3}$
}

Review article

The paper deals with the possibility of the population treat during cultural and social
events. There is a great availability of resources and processes for the production of
explosives. The paper is focused on the using of explosives, the blast wave arising in
the explosion and its impact on the environment. In the final part there is described the
effects of the explosion on the human body.
ANFO explosives, explosion, influence of explosive on the environment, blast wave,
terrorism.

\section{Introduction}

The violence is a part of human behaviour and many of its demonstrations are existed. The violence can be considered as a means of an achievement of own interests. Security systems can be overcame and the people can be frightened with the violence. It is an integral part of the equipment used by terrorist groups.

The creation of safety environment mainly for the protection of the lives and health of all involved persons is required during mass cultural and social events. There is a need to protect the property of people besides their life and health. But the priority is to protect person lives and health.

The safe environment is created in the security environment introducing the protective measures. The protective measures can be divided into groups: passive and active protective measures, measures of physic safety and modal-organisation measurements. However, the implementation of protective measures does not guarantee the elimination of risk, but it increases the resistance of a protected interest to phenomena that are able to undermine its security (Loveček and Reitšpís, 2011).

\section{Materials and methods}

The field test of different explosives was done. The aim of field test was to measure the blast wave which is created in the explosion.

The industrial explosives are used by terroristic groups. Industrial explosives differ from military ones in lower stability and a lower price. More than $95 \%$ of all terrorist attacks are carried out using ANFO (ammonium nitrate - fuel oil) explosives in three different variants (ammonium nitrate with oil, ammonium nitrate with oil and aluminium powder or ammonium nitrate with oil and trinitrotoluene). They are called DAP in the Slovak and the Czech Republic (Jangl and Kavický, 2012).

The industrial ANFO explosives were used in field tests, especially POLONIT, DAP - 2 and DAP - E. Their choice was influenced by the availability of resources for the production and also relatively simple and available manufacturing practices. For every tested explosives the influence of buster to the pressure value of blast wave.

\section{Brief characteristics of used industrial explosives}

$D A P-2$ is a mixture of ammonium nitrate, petroleum and colorant. The explosive is of loose consistency, red in colour and is used for blasting on the surface as well underground without the danger of gas, vapour and dust explosions as a rock mining explosive.

$D A P$ - E The explosive is a mixture of ammonium nitrate, methyl esters of higher fatty acids, vegetable oil and red dye. The explosive is of loose consistency, red-grey in colour and it can be used in blasting operations on the surface as well as in the underground in an environment without the danger of gas, vapour and dust explosions as a rock mining explosive. Military explosives $P L N p-10$ is known

University of Žilina, Faculty of Special Engineering, Žilina, the Slovak Republic, Stefan.Jangl@fsi.uniza.sk

University of Žilina, Faculty of Special Engineering, Žilina, the Slovak Republic, Lucia.Figuli@fsi.uniza.sk

University of Žilina, Faculty of Special Engineering, Žilina, the Slovak Republic, Zuzana.Ligasova@fsi.uniza.sk 
as Semtex 10 and it is intended to be a special kind of blasting. For its properties it is used for destruction work under water and as busters of explosives. The explosive is plastic, easily forming, grey and to grey - black colour (Jangl and Kavický, 2012).

Measurements were made in the collaboration with the Military Technical and Testing Institute Zahorie (VTSU Zahorie) in the part of CAMP PROTECTION - research of material protective properties used for the infrastructures focusing on the threat of an attack with explosive devices. Methodology of measurements was according to ITOP 4-2.822. It is an international standard describing the methodology of electronic measurement of blast pressure and high impulses of the noise.

The free place with the diameter of $30 \mathrm{~m}$ was prepared for the test field. The room for the secure people hiding, measurement apparatus and equipment was prepared. In the centre of place there were the stand for explosives and the sensors protected against the effects of debris in the certain distances there were placed. Four sensors in the height of 1.6 metres above the surface and in the distances 2, 5, 10 a 20 metres from the explosives were used. In the test there were also used sound level meter, pressure gauge, thermometer and measuring equipment wind speed and direction, high speed camera and ammunition material.

\section{Results}

The explosion has primary and secondary effects on the surroundings. Among the primary effects belong blast wave, light, heat and sound. The secondary effects are fire, debris effect, structures damage and psychological effect (Jangl and Kavický, 2012). The field tests were focused on the measurements of the blast wave, and its influence of the objects. The different values were measured.

Maximum blast wave are in Tab. 1 and in Fig.1.

Tab. 1 Maximum values of explosives

\begin{tabular}{|c|c|c|c|}
\hline \multirow{2}{*}{$\begin{array}{c}\text { Distance of } \\
\text { sensor }[\mathbf{m}]\end{array}$} & \multicolumn{3}{|c|}{ Used explosives } \\
\cline { 2 - 4 } & $\begin{array}{c}\text { POLONIT } \\
\mathbf{1 0 0 0} \mathbf{g}\end{array}$ & $\begin{array}{c}\text { DAP - 2 } \\
\mathbf{1 0 0 0} \mathbf{g}\end{array}$ & $\begin{array}{c}\text { DAP - E } \\
\mathbf{1 0 0 0} \mathbf{g}\end{array}$ \\
\cline { 2 - 4 } & \multicolumn{3}{|c|}{ Maximum blast wave [kPa] } \\
\hline 2 & 137,5 & 82,9 & 120,9 \\
\hline 5 & 30,0 & 20,2 & 29,0 \\
\hline 10 & 14,8 & 11,1 & 13,3 \\
\hline 20 & 6,9 & 5,8 & 7,0 \\
\hline
\end{tabular}

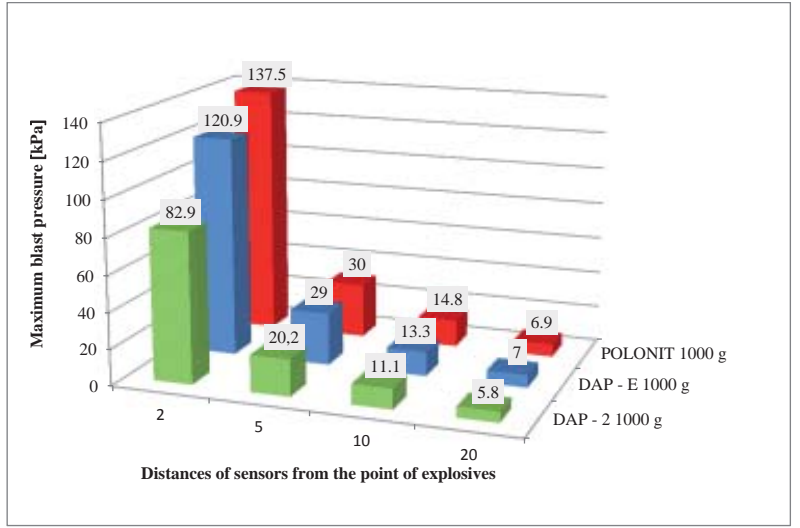

Fig. 1 Graphical representation of maximum blast wave

\section{Cultural and social events as a target of terrorist attack}

Terrorist groups try to focus their activity on the controlling different targets. What can be considered as a potential target depends on the interest of terrorist group. If the aim of the attack is to attract the attention we talk about the advertising goal. The attack can be a single violent act in order to dispose of a specific person or object. The objective may also be to kill and to injure many people without focusing on a specific person. The attack may be directed also at a strategic objective; in this case, the intention is to destabilize the functioning of the state or region. Targets of terrorist groups can be divided into main objectives - the objects of critical infrastructure elements and secondary objectives, which don't have strategic importance from the viewpoint of safety (Gašpierik and Jangl, 2010).

If we deal with the problem of the person protection when the social and cultural event occurs, we have to consider the possibility, that such assembly can be the target for terrorist groups. Places with the high amount of person are one of terrorist group target. The attacks are not focused on the specific person, but they are made to kill and injure as many "anonymous" people. Attendant phenomenon is to induce fear and panic. After these attacks, there are changes of security measures to future similar attacks timely detect and prevent. These measures, however, people can make feel as limiting of their own freedom. Although this situation is a success for the terrorists, because it means that people are afraid of them and they must limit their activities.

\section{The influence of explosion on persons}

The influence of explosion on person depends on different factors. They are mainly the size and 
sort of charge, the distance of person from the epicentre of the explosion, the position of a person in space, fragments and the thermal effect and etc. It is obvious that the greatest effect is in the centre of explosion.

Injury caused with explosion can be divided into (Janovský, 2008):

- Blast syndrome - effect of blast wave, which causes approximately $11 \%$ of all injuries.

- Fragments injuries - wounds cause with debris of explosive and the surroundings.

- Burns thermal effect of explosion.

- Crush syndrome - different consequences after the explosion influencing surroundings with the effects on the persons, demolition of buildings and regaling of persons.

- Direct injuries - called as primary consequences. They are wounds arising due to sharp increase in pressure to very high values. Primary effect is mainly damage of lungs. The explosion pressure rise occurs, and consequently may cause compression of the chest and lung injury. This injury is related for example with haemoptysis and cyanosis. Furthermore, there is damage of the eardrums and the inner ear. Eardrum damage depends on the person's head rotation with respect to the action of the pressure wave. High blood pressure is sensitive and abdomen. They often cause bowel perforation and internal bleeding. Other common injuries are cracking coils or brain damage. (Šmejkal, 2011)

Indirect injuries - can be divided into secondary and tertiary consequences.

- Secondary consequences are caused by the impact of various debris and fragments derived directly from explosives, explosive device or surrounding objects. Affect the child's eyes, deep muscle injury, tearing the jugular vein, amputation unprotected parts of the body. (Šmejkal, 2011)

Fragments resulting from the explosion can be divided into primary and secondary. Primary fragments results from the explosive, explosive device. They are the packing of explosive or small parts daily use intentionally spread near the explosive. Such parts are nails, screws, lead balls and other small subjects, so that can fly in air several hundred or thousands meters per second, causing extensive injury to person even over long distances. Secondary fragments are fragment from the objects placed near the explosion. They have shorter flying range than primary fragments and their size is about the size of debris. The tertiary consequence is for example the injury of person, who was thrown into a solid obstacle by the blast wave. Tertiary consequences are the most significant when people are upright during an explosion. (Janovský, 2008)

The effect of blast waves on humans is also influenced by the position of a person during an explosion, if he/she is in a building or outdoors, and also by the point where an explosion is. In the building there is threatens by fragments, especially glass shards and falling the parts of buildings. The Fig. 2 shows the percentage of each type of injury resulting from the explosion of the total amount of injury.

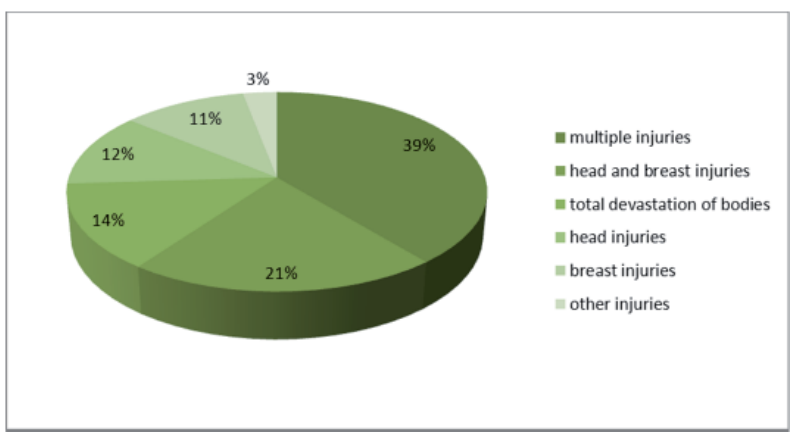

Fig. 2 Graphical representation of the percentage of each type of injury resulting from the explosion (Jangl and Kavický, 2012)

Tab. 2 Blas wave effects on persons and objects (Makovička, 2014; Kroupa, 2010)

\begin{tabular}{|c|c|c|}
\hline $\mathbf{N}$. & $\begin{array}{l}\text { Pressure } \\
\text { VRV } \Delta \mathbf{p}_{\mathbf{v}} \\
{[\mathrm{kPa}]}\end{array}$ & Effects \\
\hline 1. & to 0.5 & - without demages. \\
\hline 2. & $0.5-5.0$ & $\begin{array}{l}\text { - windows breaking - fragments } \\
\text { effect. }\end{array}$ \\
\hline 3. & $5.0-20.0$ & $\begin{array}{l}\text { - windows demage and light building } \\
\text { demage - fragments effect. }\end{array}$ \\
\hline 4. & $10.0-30.0$ & $\begin{array}{l}\text { - partially building collapse - person } \\
\text { cluttering. }\end{array}$ \\
\hline 5. & 15.0 & - fall of standing person. \\
\hline 6. & 34.0 & - rupture of eardrums. \\
\hline 7. & $50.0-250.0$ & $\begin{array}{l}\text { - fall of the less resistant stone, brick } \\
\text { and wood buildings - smothering } \\
\text { people. }\end{array}$ \\
\hline 8. & 150.0 & - fatal damage to the body. \\
\hline 9. & 500.0 & $\begin{array}{l}\text { collapse or serious damage to } \\
\text { massive reinforced concrete } \\
\text { structures. }\end{array}$ \\
\hline
\end{tabular}

\section{Conclusion}

We consider social and cultural events as a potential target of terrorist attack. We looked at the obtainable explosives from the sources available for 
breach safety of such meeting. These explosions act on their surroundings, living and dead, by various influences. The blast wave influence on the effect of the explosion on the environment and this was a reason why we aimed a part of the paper to find out the pressure in the head of the shock wave emerging in the explosion. Published results come from tests made in VTSU Zahorie. We detected pressure value resulting from the one kilogram charges explosions selected explosives.

Comparing experimental maximal results (Tab. 1) and values (Makovička, 2014; Kroupa, 2010) we can conclude that by the explosion of one kilogram charge of POLONIT with the buster could cause the fatal person injury, building damage, cracks in concrete and collapse of wooden building to the distance of 2 meters from the explosion place. A similar effect should be DAP-E at the distance of 2 metres.

The lowest values were found in explosive DAP - 2 from the tested explosives, there was a maximum value found $82.9 \mathrm{kPa}$. This value is sufficient for light damage of reinforced concrete structures, burst eardrums and fall of standing persons.
The lowest values observed for the tested explosives were from $5.8 \mathrm{kPa}$ to $7 \mathrm{kPa}$ at the distance of 20 metres from the explosion site. Such pressure would cause the collapse of light wooden constructions, complete destruction of windows, roofs, and thin walls of normal buildings. This could cause damage of health due to fragments effect or people cluttering.

Effect of the tested explosives does not seem very destructive, but it should be aware that they were used only $1000 \mathrm{~g}$ charges independently. Due to the availability of raw materials for the production of ANFO explosives and their effectiveness we consider that it is necessary to deal with the threat of mass cultural and social events from such attacks as well as it is important to solve ways of increasing resistance of buildings against such attacks .

We developed the outline description of the impact of the explosion on the persons in this paper, for completeness of the paper and the emphasize of the need to protect objects against an attack using explosives

\section{References}

GAŠPIERIK, L., JANGL, Š. (2010). Ochrana proti terorizmu. Žilina: EDIS - vydavatel'stvo Žilinskej univerzity, 2010. 221p. ISBN 978-80-970410-5-2. (in Slovak)

JANGL, Š., KAVICKÝ, V. (2012). Ochrana pred účinkami výbuchov výbušnín a nástražných výbušných systémov. Žilina: Jana Kavická - KAVICKY, 2012. 294 p. ISBN 978-80-971108-0-2. (in Slovak)

JANOVSKÝ, B. (2008). Prednáška na tému: Pi̊sobení vzdušných rázových (tlakových) vln na zařizení a osoby. Pardubice: Univerzita Pardubice, Katedra teorie a tehcnologie výbušnín, 2008. (in Czech)

KROUPA, L. (2010). Prednáška na tému: Hrozba bombových útokov. Brno: Univerzita obrany Brno, Česká republika, 2010. (in Slovak)

LOVEČEK, T., REITŠPÍS, J. (2011). Projektovanie a hodnotenia systémov ochrany objektov. Žilina: EDIS vydavatel'stvo Žilinskej univerzity, 2011. 281p. ISBN 978-80-554-0457-8. (in Slovak)

MAKOVIČKA, D. (2014) Prednáška na tému: Přibližné stanovení odezvy stavební konstrukce zatižené výbuchem. [online] Projekt celoživotního vzdělávání v oblasti protivýbuchové ochrany staveb. [2014-02-17]. Available at: http://pvoch.cvut.cz/. (in Czech)

ŠMEJKAL, J. (2011). Ošetřování poranění způsobené tlakem v boji. Diplomová práca. Čelákovice: VOŠ, SOŠ a ZŠ MILLS, s.r.o., 2011. (in Czech) 